Dunamis: Jurnal Teologi dan Pendidikan Kristiani

Volume 3, Nomor 2 (April 2019)

ISSN 2541-3937 (print), 2541-3945 (online)

http://www.sttintheos.ac.id/e-journal/index.php/dunamis

\title{
Pendekatan Model Pembelajaran Berbasis Portofolio dalam Meningkatkan Tanggung Jawab Belajar Mahasiswa di Sekolah Tinggi Teologi
}

\author{
Sarah Andrianti \\ Sekolah Tinggi Teologi Intheos Surakarta \\ sarahandrianti@gmail.com
}

\begin{abstract}
This research aimed to describe Portfolio-Based Instruction (PBI) in improving student learning responsibility at Theological Seminary. This research used qualitative and literature study technic. This research brought about the conclusion when PBI applied by consider the compatibility of study materials and purposes of learning than PBI can improves student learning responsibility at Theological Seminary.
\end{abstract}

Keywords: Learning model; Portfolio; Learning responsibility; Theological Seminary.

\begin{abstract}
Abstrak
Penelitian ini bertujuan mendeskripsikan pendekatan model pembelajaran berbasis portofolio (MPBP) dalam meningkatkan tanggung jawab belajar mahasiswa di Sekolah Tinggi Teologi (STT). Penelitian menggunakan jenis kualitatif yang bersifat studi pustaka (library research). Penelitian ini menghasikan kesimpulan apabila MPBP diterapkan dengan mempertimbangkan kecocokan materi kuliah dan tujuan perkuliahan, maka dapat meningkatkan tanggung jawab belajar mahasiswa di Sekolah Tinggi Teologi.
\end{abstract}

Kata Kunci: Model pembelajaran; Portofolio; Tanggung jawab belajar; Sekolah Tinggi Teologi. 


\section{PENDAHULUAN}

Pendidikan memegang peranan inti dalam membentuk generasi yang berkualitas. Semakin baik pendidikan yang ditempuh, semakin berkualitas generasi yang dihasilkan. Kaum intelektual tidak terbentuk secara instan, namun melalui proses ketekunan belajar yang konsisten dan pantang menyerah. Kondisi tersebut memberi pengaruh yang sistematis dan masif terhadap taraf pendidikan melalui sumber daya manusia yang unggul. Dengan melihat fakta bahwa baik negara berkembang maupun negara maju sekalipun masih menemui permasalahan seputar pendidikan, menandakan bahwa pendidikan merupakan kebutuhan yang krusial sekaligus mandat mulia dalam kehidupan manusia individu maupun global. Mencapai suatu tujuan yang hayati sesuai UndangUndang Nomor 20 Tahun 2003 tentang Sistem Pendidikan Nasional, berarti siap menghadapi berbagai tantangan dalam proses mengejawantahkannya. Demikian juga dalam mencapai tujuan pendidikan terdapat berbagai permasalahan yang harus dientaskan. Indonesia merupakan negara berkembang yang tidak memandang pendidikan dengan sebelah mata. Namun masalah yang ada di Indonesia bahwa pendidikan tidak memberikan hasil seperti apa yang diharapkan, dan siswa tidak dapat belajar dengan baik karena tidak dapat menangkap apa yang diajarkan oleh guru. ${ }^{1}$

Dalam mengatasi permasalahan umum tersebut, telah sekian lama dihadapi dengan cara yang umum yaitu dengan guru maupun siswa terus belajar sepanjang hayat. Maka dalam mengusahakan percepatan mencapai tujuan pendidikan perlu suatu evaluasi dan inovasi dalam cara belajar secara berkelanjutan.

Belajar merupakan modifikasi atau memperteguh kelakuan melalui pengalaman. Konsep ini memaknai belajar sebagai suatu proses atau suatu kegiatan dan bukan sekedar suatu hasil atau tujuan. Proses dalam belajar menjadi lebih penting karena siswa bukan hanya menerima sejumlah pengetahuan tetapi juga mendapatkan keterampilan dan nilai-nilai yang bermakna dalam kehidupan. ${ }^{2}$ Terkait permasalahan seputar belajar juga dihadapi dalam pendidikan jenjang perguruan tinggi dan sederajat. Tentu semakin tinggi jenjang pendidikan maka pelaku belajar mamiliki tanggung jawab yang lebih besar dalam belajar maupun menghadapi tantangan belajar tersebut. Kesempatan untuk kuliah di perguruan tinggi tidak dimiliki oleh semua orang. Namun banyak anak muda

\footnotetext{
${ }^{1}$ Marno, "Optimalisasi Media Pembelajaran Melalui Teknik Problem Based Instruction Untuk Meningkatkan Hasil Belajar Kelas XI SMA Negeri 1 Surakarta Tahun 2016/2017," Jurnal Pendidikan Konvergensi 20, no. 67 (2017).

${ }^{2}$ Mukhamad Murdiono, Strategi Pembelajaran Kewarganegaraan Berbasis Fortofolio, 2012.
} 
yang mendambakan untuk dapat kuliah di sebuah perguruan tinggi, terutama jika kampus yang diminati merupakan kampus yang ternama. Pada kenyataannya terdapat mahasiswa yang setelah diterima di perguruan tinggi favorit kurang bersemangat dan kurang bertanggung jawab dalam belajar. Sedangkan banyak anak muda yang cerdas justru tidak memiliki kesempatan untuk belajar di perguruan tinggi oleh berbagai faktor. Di sisi lain, masalah belajar dalam perguruan tinggi juga dapat muncul dari dosen. Terdapat dosen yang tidak tahu menggunakan model pembelajaran yang tepat untuk menangani mahasiswa yang kurang menghiraukan tanggung jawab belajar dan tugas yang mereka terima, atau dosen tersebut mengetahui berbagai model pembelajaran yang efektif namun tidak menerapkannya dalam mata kuliah yang dia ampu. Diperlukan ketepatan dosen dalam memilih model pembelajaran, karena akan sangat berpengaruh terhadap kwalitas dan keberhasilan proses pembelajaran. ${ }^{3}$

Sekolah Tinggi Teologi (STT) tidak terlepas dari tantangan serupa. Pergumulan

\footnotetext{
${ }^{3}$ Dyan Desi Madyarini and Abdul Gafur, "KOMPARASI MODEL PEMBELAJARAN PORTOFOLIO DAN PBL TERHADAP HASIL BELAJAR IPS DI SMPN KECAMATAN SEWON," Harmoni Sosial: Jurnal Pendidikan IPS 2, no. 2 (September 30, 2015): 126-134, accessed April 14, 2019,

https://journal.uny.ac.id/index.php/hsjpi/article/view 17664 .
}

untuk menghasilkan mahasiswa yang berkualitas dalam lingkungan teologi mempengaruhi setiap dosen dalam memberikan tugas yang berbobot dan mendorong prestasi mahasiswa. Pemberian tugas belajar tersebut, selain bermaksud meningkatkan intelektualitas juga untuk memupuk rasa tanggung jawab mahasiswa, sehingga mereka juga akan terbiasa bertanggung jawab dalam kegiatan seharihari di keluarga, gereja, dan masyarakat. Lingkungan pelayanan gereja dan masyarakat yang menjadi area aktivitas bagi mahasiswa teologi memberi kesempatan untuk menjadi dampak serta menyalurkan pemahaman dan mempraktikan nilai-nilai teologi yang telah mereka pelajari. Selain itu, sekolah yang dalam pada itu menerapkan Kurikulum 2013 juga menuntut kesiapan lulusan STT untuk implementasinya. ${ }^{4}$ Oleh karena itu setiap dosen Sekolah Tinggi Teologi perlu menerapkan model pembelajaran yang efektif dalam menunjuang cara belajar mahasiswa mencapai tujuan pembelajaran.

Dalam susunan mata kuliah berdasarkan garis besar kurikulum Sekolah Tinggi Teologi, beberapa diantaranya memfokuskan pada menghasilkan produk mahasiswa berupa karya ilmiah mandiri

\footnotetext{
${ }^{4}$ Ruwi Hastuti, "KESIAPAN SEKOLAH TINGGI TEOLOGI MENGHADAPI KURIKULUM 2013," Jurnal Antusias 3, no. 5 (June 1, 2014): 103-116, accessed April 15, 2019, http://sttintheos.ac.id/ejournal/index.php/antusias/article/view/15.
} 
yang terstruktur dan berkelanjutan, karena baik antar matakuliah maupun antar materi dalam setiap matakuliah telah dirancang secara matang sehingga saling berintegrasi dan sistematis. Dengan melihat keunikan yang strategis ini, perlu adanya dokumentasi dalam proses kegiatan belajar mengajar yang diistilahkan sebagai portofolio pembelajaran ${ }^{5}$ dosen dapat menggunakan model pembelajaran Portofolio yang merupakan model pembelajaran dengan tujuan memperoleh "karya terpilih" mahasiswa di antara serangkaian tugas yang diberikan. ${ }^{6}$ Melalui "karya terpilih" berarti meghasilkan karya ilmiah berkualitas sekaligus memberi apresiasi bagi setiap mahasiswa atas partisipasinya meningkatkan kualitas pendidikan melalui hasil pemikiran mereka sendiri, dan dorongan bagi mereka untuk melaksanakan tugas belajar secara bertanggung jawab.

Hubungan antara pendekatan model pembelajaran berbasis portofolio dengan meningkatkan tanggung jawab belajar peserta didik sebelumnya telah diteliti oleh

\footnotetext{
${ }^{5}$ Isyatul Karimah, Wahyu Sakti Gunawan Irianto, and I Made Wirawan, "PENERAPAN PENILAIAN PORTOFOLIO PEMBELAJARAN GURU SMKN DI KELAS X PADA MATA PELAJARAN PEMROGRAMAN WEB," Jurnal Pendidikan: Teori, Penelitian, dan Pengembangan 2, no. 11 (November 1, 2017): 1482-1488, accessed April 14, 2019,

http://journal.um.ac.id/index.php/jptpp/article/view/ 10178.

${ }^{6}$ Tukiran Taniredja, Model-Model Pembelajaran Inovatif Dan Efektif (Bandung: Alfabeta, 2017).
}

Birgin dan Baki dalam "The Use of Portfolio to Assess Student's Performance" dengan hasil sebagai berikut, "It is necessary to assess the students' performances as an individual or in a group during the learning process rather than assessment with traditional methods or multiplechoice methods. Portfolios are alternative assessment methods to observe students' developments and assess their performances during learning process. Moreover, portfolios are assessment tool based on contemporary learning approach such as constructivist learning theory, multiple-intelligences theory and brainbased learning theory (Sangat perlu untuk menilai keahlian peserta didik secara individual maupun berkelompok selama proses pembelajaran lebih dari sekedar menggunakan penilaian klasik ataupun perpaduan penilaian lainnya. Portofolio adalah metode untuk mengamati perkembangan kemampuan peserta didik selama proses pembelajaran. Selebihnya, portofolio adalah instrumen penilaian berdasarkan pembelajaran kontemporer seperti pembelajaran konstruktif, pembelajaran keahlian jamak, dan pembelajaran kognitif)." ${ }^{, 7}$ Berdasarkan hasil penelitian tersebut, model portofolio

\footnotetext{
${ }^{7}$ Osman Birgin and Baki Adnan, "The Use of Portfolio to Assess Student's Performance," Journal of Turkish Science Education 4, no. 2 (2007), http://www.tused.org/internet/tused/sayilar/defaultar chive.asp?islem $=$ detaylar\&id $=111$.
} 
memusatkan pembelajaran pada peserta didik sehingga tujuannya yang transparan adalah meningkatkan tanggung jawab belajar. Hasil serupa juga dinyatakan oleh Mokhtaria dalam penelitian "The Use of Portfolio as an Assessment Tool" yaitu, "While portfolios provide teachers and administrators with diverse, multi-source information for the purposes of assessment and evaluation, the core reason for embracing portfolio work in the enterprise of teaching and learning is to inspire students to become active, engaged, and reflective learners. (Jika portofolio menyajikan kepada guru dan administrasi sekolah tentang berbagai macam informasi seputar penilaian dan evaluasi, alasan dasar memahami portofolio dalam mengusahakan proses pembelajaran adalah untuk menginspirasi peserta didik menjadi aktif, terlibat, dan reflektif)."8

Berdasarkan dua hasil penelitian tersebut, Portofolio secara administratif mengarahkan peserta didik menjadi aktif dalam pembelajaran, dan secara transparatif mengarahkan peserta didik mejadi bertanggung jawab dalam belajar. Portofolio telah diteliti dan dibuktikan mampu meningkatkan tanggung jawab belajar dalam pembelajaran secara umum, sehingga menawarkan sebuah kemungkinan

\footnotetext{
${ }^{8}$ Lahmer Mokhtaria, "The Use Of Portfolio As An Assessment Tool" 4, no. 07 (2015): 170-172.
}

besar untuk dapat juga diterapkan dalam matakuliah secara spesifik pada Sekolah Tinggi Teologi. Berdasarkan latar belakang masalah tersebut, maka penelitian ini bertujuan untuk mendeskripsikan pendekatan model pembelajaran berbasis portofolio (MPBP) dalam meningkatkan tanggung jawab belajar mahasiswa di Sekolah Tinggi Teologi (STT).

\section{METODE PENELITIAN}

Penelitian ini adalah penelitian kualitatif yang bersifat studi pustaka (library research) dengan menggunkan buku-buku dan literatur-literatur lainnya sebagai objek yang utama ${ }^{9}$. Jenis penelitian yang digunakan adalah kualitatif, yaitu penelitian yang menghasilkan informasi berupa catatan dan data deskriptif yang terdapat di dalam teks yang diteliti. Dengan penelitian kualitatif, perlu dilakukan analisis deskriptif. Metode analisis deskriptif memberikan gambaran dan keterangan yang secara jelas, objektif, sistematis, analitis dan kritis mengenai objek yang diteliti. Pendekatan kualitatif yang didasarkan pada langkah awal yang ditempuh dengan mengumpulkan data-data yang dibutuhkan, kemudian dilakukan klasifikasi dan deskripsi.

Dalam penelitian kepustakaan, metode yang digunakan untuk

\footnotetext{
${ }^{9}$ Sutrisno Hadi, Statistik II (Jakarta: Rineka Cipta, 1995).
} 
mengumpulkan data penelitian berupa datadata kepustakaan yang telah dipilih, dicari, disajikan dan dianalisis. Sumber data penelitian ini mencari data-data kepustakaan yang substansinya membutukan tindakan pengolahan secara filosofis dan teoritis. Studi pustaka di sini adalah studi pustaka tanpa disertai uji empirik ${ }^{10}$. Data yang disajikan adalah data yang berbentuk kata yang memerlukan pengolahan supaya ringkas dan sistematis. Analisis adalah serangkaian upaya sederhana tentang bagaimana data penelitian pada gilirannya dikembangkan dan diolah ke dalam kerangka kerja sederhana ${ }^{11}$. Data yang sudah terkumpul kemudian dianalisis untuk mendapatkan informasi, namun terlebih dahulu data tersebut diseleksi atas dasar reliabilitasnya. Dalam penelitian ini menggunakan teknik analisi data berupa analisis isi (content analysis). Analisis isi merupakan analis ilmiah tentang isi pesan suatu data. Dua aspek yang akan dikaji dalam artikel ini adalah model pembelajaran berbasis portofolio dan tanggung jawab belajar mahasiswa Sekolah Tinggi Teologi.

\section{Model Pembelajaran Berbasis Portofolio}

$$
\text { Model pembelajaran adalah }
$$
kerangka konseptual yang melukiskan

\footnotetext{
${ }^{10}$ Muhadjir Noeng, Metodologi Penelitian Kualitatif (Yogyakarta: Rake Sarasin, 1998).

${ }^{11}$ Mestika Zed, Metode Penelitian Kepustakaan (Jakarta: Yayasan Obor Indonesia, 2004).
}

prosedur sistematis dalam mengorganisasikan pengalaman belajar untuk mancapai tujuan belajar tertentu dan bersifat sabagai pedoman bagi perangsangan pembelajaran para guru dalam merencanakan dan melaksanakan

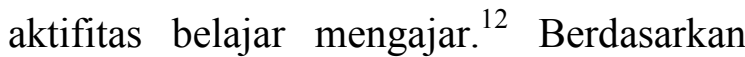
definisi tersebut, maka model pembelajaran yang pengajar gunakan dalam memberikan materi akan menentukan motivasi, proses, dan hasil serta evaluasi dalam pembelajaran tersebut. Maka penggunaan model pembelajaran bukan serta merta karena model tersebut unik, tenologis, atau menyenangkan saja tetapi lebih kepada menyesuaikan isi materi dan tujuan pembelajaran yang hendak dicapai.

Portofolio berasal dari bahasa Inggris "portfolio" yang artinya dokumen atau surat-surat. Dapat juga diartikan sebagai kumpulan kertas-kertas berharga dari suatu pekerjaan tertentu. Pengertian portofolio dalam konteks penelitian ini adalah suatu kumpulan pekerjaan siswa dengan maksud tertentu dan terpadu serta diseleksi menurut panduan-panduan yang telah ditentukan ${ }^{13}$. Portofolio juga sering diartikan dengan karya terpilih dari seorang siswa atau berupa karya terpilih dari satu kelas secara keseluruhan yang bekerja

12 Trianto, Mendesain Model Pembelajaran InovatifProgresif (Jakarta: Kencana Prenada Media Group, 2010).

${ }^{13}$ Arnie Fajar, Portofolio Dalam Pelajaran IPS

(Bandung: PT Remaja Rosdakarya, 2002). 
secara kooperatif. Istilah "karya terpilih" merupakan kata kunci dari portofolio. Maknanya adalah bahwa yang harus menjadi akumulasi dari segala sesuatu yang ditemukan para siswa dari topik mereka harus membuat bahan-bahan yang menggambarkan usaha terbaik siswa dalam mengerjakan tugas-tugas yang diberikan kepadanya, serta mencakup pertimbangan terbaiknya tentang bahan-bahan mana yang penting. ${ }^{14}$ Dengan demikian portofolio merupakan instrumen untuk mengeksplorasi kemampauan terbaik dari masing-masing siswa dalam belajar atau kemampuan terbaiknya dalam bekerja sama dengan rekan belajar.

Model pembelajaran berbasis portofolio (MPBP) atau disebut juga Portfolio-Based Instruction (PBI) merupakan alternatif cara belajar siswa aktif (CBSA) dan cara mengajar guru aktif (CMGA). Menurut Fajar dalam model pembelajaran ini sebelum, selama dan sesudah proses belajar mengajar guru dan siswa dihadapkan pada sejumlah kegiatan. ${ }^{15}$ Sedangkan menurut Budiono dalam Setiadi, model pembelajaran berbasis portofolio merupakan satu bentuk dari praktik belajar yaitu suatu inovasi pembelajaran yang dirancang untuk membantu peserta didik memahami teori secara mendalam melalui

\footnotetext{
${ }^{14}$ Taniredja, Model-Model Pembelajaran Inovatif Dan Efektif.

${ }^{15}$ Fajar, Portofolio Dalam Pelajaran IPS.
}

pengalaman belajar praktik-empirik. ${ }^{16}$ Berdasarkan beberapa definisi tersebut, model pembelajaran berbasis portofolio berarti pendekatan pembelajaran yang pengajar gunakan melalui pemberian tanggung jawab tugas individu atau kelompok sehingga menghasilkan kumpulan dokumen atau tugas-tugas yang diorganisasikan dan dipilih untuk mencapai tujuan pembelajaran sekaligus sebagai bukti nyata dari siswa atau kelompok siswa tersebut memiliki pertumbuhan dalam bidang pengetahuan, sikap, dan keterampilan.

Dophan dalam Supriyadi 17 mengemukakan ciri-ciri portofolio adalah sebagai berikut: (1) Ada keterlibatan langsung hasil kerja/karya siswa secara nyata; (2) Mengumpulkan beberapa kasil kerja/karya yang terbaik;

Mengumpulkan dan menyimpan hasil kerja siswa; (4) Memilih kriteria untuk menilai portofolio hasil kerja siswa; Mengharuskan siswa untuk menilai dirinya secara terus menerus berdasarkan hasil portofolionya; (6) Menentukan waktu untuk membahas portofolio; (7) Melibatkan orang tua dan masyarakat dalam proses penilaian portofolio. Model pembelajaran berbasis

\footnotetext{
${ }^{16}$ Elly M Setiadi, Ilmu Sosial Dan Budaya Dasar (Jakarta: Kencana, 2006).

${ }^{17}$ Acep Supriadi, Kemampuan Guru Memanfaatkan Asesmen Portofolio Dalam Meningkatkan Mutu Belajar Pendidikan IPS Di Sekolah Dasar (Bandung: UPI, 1997).
} 
portofolio mengacu pada sejumlah prinsip dasar pembelajaran yaitu (1) Prinsip Belajar Siswa Aktif; (2) Kelompok Belajar Kooperatif; (3) Pembelajaran Partisipatorik; (4) Reactive Teaching; (5) Joyfull Learning. Model pembelajaran tersebut menganut prinsip dasar bahwa belajar itu harus dengan suasana yang menyenangkan (joyfull learning). Melalui model ini siswa diberi keleluasaan untuk memilih tema belajar yang menarik bagi dirinya. Pengalaman terjun ke masyarakat seacara langsung adalah pengalaman belajar riil yang menyenangkan dan melatih sejumlah kompetensi untuk hidup bermasyarakat.

\section{Tanggung Jawab Belajar Mahasiswa Sekolah Tinggi Teologi}

Tanggung jawab merupakan suatu sikap dan perilaku seorang individu dalam melaksanakan tugas dan kewajiban yang harus ia lakukan, baik tugas terhadap Tuhan Yang Maha Esa, negara, lingkungan dan masyarakat serta dirinya sendiri ${ }^{18}$. Sikap tanggung jawab sangat penting dimiliki dan dibiasakan oleh setiap orang sejak dini karena akan menjadi dasar tanggung jawab pada masa depannya. Tanggung jawab utama pelajar adalah belajar. Dalam rangka meningkatkan tanggung jawab belajar mahasiswa, dosen memiliki peran penting

\footnotetext{
${ }^{18}$ Darmiyati Zuchdi, Pendidikan Karakter: Konsep Dasar Dan Implementasi Di Perguruan Tinggi (Yogyakarta: UNY Press, 2013).
}

di kampus, misalnya dalam memberikan perkuliahan. Meskipun mahasiswa dalam sisi usia dianggap sudah harus menyadari tanggung jawabnya, namun dosen tidak lepas juga dari tanggung jawab untuk tetap memotivasi dan mengawasi mereka. Penerapan metode pembelajaran yang diberikan dosen harus sesuai, seperti pemberian tugas. Pemberian tugas memiliki kelebihan adalah dapat mengembangkan daya pikir maha siswa, kreativitas, kemandirian serta tanggung jawab ${ }^{19}$. Namun pemberian tugas juga memiliki kekurangan, salah satunya adalah perasaan bosan akibat pemberian tugas yang tidak bervariasi. Oleh karena itu, dosen harus lebih inovatif dan tepat sasaran dalam memberikan tugas kepada mahasiswa. Sebagai seorang perancang dalam pembelajaran, dosen sangat berperan dalam menentukan berhasil tidaknya pencapaian tujuan pembelajaran. ${ }^{20}$

Tanggung jawab belajar mahasiswa dalam setting STT pertama-tama dapat dilihat berdasarkan visi Perguruan Tinggi Teologi/ Agama Kristen (PTT/AK) yaitu

\footnotetext{
${ }^{19}$ Syaiful Bahri Djamarah, Strategi Belajar Mengajar (Jakarta: Rineka Cipta, 2013).

${ }^{20}$ Rohani Rohani and Tri Indah Kesumawati, "Pengaruh Pembelajaran Berbasis Portofolio Dan Kemampuan Awal Terhadap Hasil Belajar Mahasiswa Prodi PIAUD," AL-ATHFAL : JURNAL PENDIDIKAN ANAK 4, no. 2 (December 31, 2018): 187-198, accessed April 14, 2019, http://ejournal.uinsuka.ac.id/tarbiyah/index.php/alathfal/article/view/4 $2-06$.
} 
Terwujudnya Sumber Daya Manusia Kristiani bermutu yang dapat berperan bagi masa depan kehidupan beragama dan bergereja yang oikumenis, visioner, injili, dinamis, memiliki spiritualitas dan moral Kristiani yang bermutu dan teruji dalam semua dimensi pelayanan di gereja dalam konteks masyarakat majemuk dan bernuansa global ${ }^{21}$. Dengan melihat visi tersebut, mahasiswa perlu menyadari tujuannya belajar sehinngga juga mengerti tanggung jawab yang harus dilakukan dan langkah-langkah yang harus ditempuh untuk mencapai visi tersebut. Mahasiswa perlu memahami bahwa belajar di STT bukan semata mendapat indeks prestasi, namun bagaimana menerapkan ilmu tersebut dalam kehidupan. Lingkungan pelayanan gereja dan masyarakat yang menjadi area aktivitas bagi mahasiswa teologi memberi kesempatan untuk menjadi dampak serta menyalurkan pemahaman dan mempraktikan nilai-nilai teologi yang telah mereka pelajari.

\section{Tahapan-tahapan Model Pembelajaran}

\section{Berbasis Portofolio}

Berikut ini tahap-tahap yang dilakukan dalam proses pembelajaran menggunakan model berbasis portofolio

${ }^{21}$ Panduan Kurikulum Stratum Satu (S1) Prodi Pendidikan Agama Kristen Sekolah Tinggi Teologi Dan Sekolah Tinggi Agama Kristen Di Indonesia (Jakarta: Direktorat Jenderal Bimbingan Mayarakat Kristen, 2011). yang dapat meningkatkan tanggung jawab mahasiswa dalam pembelajaran.

\section{Memperhatikan Penjelasan Dosen}

Setiap proses pembelajaran dalam kelas perlu diikuti dengan baik dan cermat. Terkadang karena beberapa alasan mahasiswa kurang memperhatikan penjelasan dosen yang berdampak pada tugas yang diberikan tidak dapat dikerjakan dengan baik. Hal inilah yang kemudian harus dapat diubah oleh mahasiswa saat mengikuti perkuliahan. Pada dasarnya dosen memang bertugas untuk membimbing mahasiswa memahami dengan jelas apa yang dikemukakan oleh dosen, mulai dari topik-topik sampai kepada kesimpulan dari mata kuliah yang diberikan. Dalam memberikan materi, dosen tidak mungkin 100\% membagikan ilmunya oleh sebab keterbatasan waktu. Maka mahasiswa juga perlu kritis dalam mencari materi penunjuang. Sedangkan di sisi dosen juga perlu secara eksplisit memberikan materi pokok, kata kunci, dan isu-isu kontekstual yang perlu mahasiswa pelajari agar memiki dasar dan arah yang jelas ketika belajar mandiri atau mengerjakan tugas.

\section{Memperhatikan Sumber Belajar}

Dalam Association Education Communication and Technology (AECT) menyatakan bahwa semua sumber belajar 
yang baik adalah berupa data, orang, alat, teknik, lingkungan dan wujud tertentu yang dapat digunakan mahasiswa dalam belajar. $^{22}$ Sebagai pembelajar, mahasiswa dapat menggunakan semua sumber belajar yang ada. Walau ada kecenderungan mahasiswa hanya memanfaatkan apa yang tersedia, namun melalui model pembelajaran fortofolio mahasiswa dapat didorong untuk lebih aktif dalam mencari dan menggali sumber belajar yang beraneka. Hal tersebut selaras dengan prinsip pendidikan yang berpusat pada siswa. $^{23}$ Misalnya mahasiswa dalam mata kuliah Sejarah Gereja Indonesia dapat diberikan tugas untuk mengumpulkan hasil wawancara dari sumber belajar yaitu pemimpin gereja tentang sejarah gereja organisasi gereja setempat, dan bukan hanya dari buku. Dalam membaca berbagai buku atau sumber informasi lainnya, terutama pada era digital, mahasiswa perlu kritis dalam menyaring informasi. Mahasiswa juga perlu menumbuhkan mental anti plagiat, agar hasil karyanya kelak adalah asli dan tidak merugikan orang

\footnotetext{
${ }^{22}$ Bambang Warsita, Teknologi Pembelajaran: Landasan \& Aplikasinya (Jakarta: Rineka Cipta, 2008).

${ }^{23}$ Sarah Andrianti, "PENDEKATAN PEMBELAJARAN BERPUSAT PADA SISWA DALAM PENDIDIKAN AGAMA KRISTEN SEBAGAI IMPLEMENTASI KURIKULUM 2013," Jurnal Antusias 3, no. 5 (June 1, 2014): 86102, accessed April 15, 2019, http://sttintheos.ac.id/ejournal/index.php/antusias/article/view/14.
}

lain. Dosen juga perlu jeli dalam melihat kecenderungan ini, agar mahasiswa tidak membiasakan diri bergantung pada kemudahan akses yang cenderung membuat malas belajar. Kemudahan akses seharusnya dimanfaatkan agar hasil karya mahasiswa semakin berkualitas.

\section{Aktif dalam Memperluas Materi}

Proses pencarian dokumen dalam perkulihan di STT bermaksud memberikan sebuah study literatur untuk memperkaya topik pembahasan dalam perkuliahan. Contoh mata kuliah pencarian materi adalah Hermeneutik dan eksegesa. Pada bagian ini pentingnya peran aktif mahasiswa dalam pencarian dokumen setiap topik pembahasan karena akan sangat berpengaruh pada kelengkapan tugas yang akan diselesaikan. Berkaitan dengan langkah sebelumnya, keaktifan mencari dokumen dan sumber data ini sangat mahasiswa perlukan karena pembelajaran masa kini tidak bisa hanya secara textbook. Informasi bukan hanya dapat diperoleh dari buku dan internet, tetapi juga melalui interaksi dengan masyarakat. Dalam hal ini dosen perlu kreatif dalam memberikan tugas yang sekiranya dapat membuat mahasiswa berinteraksi dengan lingkungan, atau membawa mereka pada cara belajar yang lebih efektif.

Mendokumentasikan Data 
Seorang mahasiswa tidak mungkin dapat mengingat seluruh informasi yang didapat selama broses belajar atau proses pencarian jawaban. Maka mahasiswa perlu mendokumentasikan informasi-informasi tersebut. Sugiyono mendefinisikan dokumen merupakan catatan peristiwa yang sudah berlalu. ${ }^{24}$ Dokumen bisa berbentuk tulisan, gambar, rekaman suara dan video atau karya-karya momentum dari seseorang. Dokumentasi dapat dilakukan melalui catatan di kertas maupun secara digital, atau melalui perekaman audiovisual berupa rekaman suara, foto dan video sesuai dengan bentuk informasi tersebut. Apabila suatu studi kasus dilakukan secara berkelompok, setiap individu dalam kelompok perlu untuk mencari dokumen pribadi, untuk selanjutnya didiskusikan tentang dokumen mana yang hendak dipakai. Dalam hal ini mahasiswa akan teruji dalam menghadapi berbagai konflik perspektif dan bagaimana mereka mempersatukannya. Perbedaan perspektif tidak selalu menjadi sebuah kontradiksi, namun justru dapat saling melengkapi dan mendukung. Mahasiswa juga dapat saling mengenal dan menambah kekayaan intelektual.

\section{Aktif dalam Diskusi}

\footnotetext{
${ }^{24}$ Sugiyono, Metode Penelitian Kuantitatif, Kualitatif Dan Research \& Defelopment (Bandung: Alfabeta, 2013).
}

Aktif dalam diskusi dapat membangun komunikasi yang baik. Hal ini dapat dikatakan dengan komunikasi menjadi sebuah transaksi yang dapat membuat kondisi diskusi semakin alot. Misalnya isu-isu kontemporer mengenai trinitas, perceraian orang Kristen, LGBT, dan lain sebagainya. Disini peran dosen semakin minim dan peran mahasiswa semakin besar. Mahasiswa dituntut lebih aktif dan dapat menguasai diskusi dengan topik yang diberikan. Pada bagian ini mahasiswa dapat juga menjadi pengganti dosen sebagai sumber jawaban. Dalam pembagian kelompok diskusi, dosen dapat melakukan beberapa variasi, misalnya membagi kelas secara heterogen maupun homogen. Dosen juga perlu mempertimbangkan perbedaan daya tangkap, keaktivan, perbedaan suku, dan lainnya agar kesimpulan yang nantinya terbentuk benar-benar berdasarkan diskusi yang majemuk. Dengan demikian akan muncul kemungkinan alternatif jawaban dan pengetahuan yang baru baik bagi mahasiswa maupun dosen.

\section{Mempresentasikan Hasil Diskusi}

Hasil diskusi selanjutnya dipresentasikan di depan kelas. Apa yang dipresentasikan bukanlah keseluruhan materi yang telah didiskusikan, melainkan garis besar, kesimpulan dan penemuan 
setiap kelompok. Dalam diskusi hendaknya terjadi umpan balik antar kelompok agar kesimpulan atau penemuan yang telah dipaparkan dapat diuji dan diperkuat kembali. Dosen berperan sebagai moderator, monitor, dan fasilitator. Sebagai moderator berarti dosen mengendalikan jalannya diskusi tetapi bukan isi dari diskusi tersebut, dosen yang mempersilahkan ruang bertanya dan membatasi waktu setiap pembahasan. Sebagai monitor berarti dosen memberhatikan keterlibatan pemakalah maupun audien serta konten yang disampaikan apakah sesuai dengan koridor pembahasan. Sebagai fasilitator berarti dosen mendorong semua mahasiswa untuk mengambil satu kesimpulan akhir dan memberikan penjelasan tambahan atau menekankan kembali pokok-pokok diskusi yang telah dipresentasikan.

\section{Bekerja Sama Menyusun Portofolio}

Pada poin ini mengapa bekerja sama ditekankan pada pembelajaran portofolio karena hal ini merupakan inti dari pembelajaran portofolio. Dimana setiap orang dituntut tidak hanya mengembangkan kemampuan individu dan bertanggung jawab secara sendiri tetapi secara berkembang dan bertanggung jawab bersama atau sering disebut kerja tim (teamwork). Tuntutan capaian nilai yang bagus, perspektif kompetitif dan motivasi ingin menang sendiri agar dipandang hebat dan bisa diandalkan menyebabkan sebagian mahasiswa teologi semakin kuat untuk bekerja secara individu. Maka dosen perlu mempertimbangkan tugas portofolio yang diberikan, yang sekiranya dapat mendorong mahasiswa untuk komunkatif dan interaktif. Mahasiswa juga akan belajar memahami dan menerima perbedaan rekannya.

\section{HASIL DAN PEMBAHASAN}

\section{Analisis Model Pembelajaran Berbasis} Fortofolio di STT

Berdasarkan kajian teori yang telah peneliti uraikan, maka data study literatur tersebut akan dianalisa dan hasilnya akan diterapkan pada matakuliah di STT. Berikut adalah pembahasan pendekatan model pembelajaran berbasis portofolio pada beberapa matakuliah tersebut:

\section{Sejarah Gereja}

Mata kuliah Sejarah Gereja secara akademis dalam PTT/AK di Indonesia biasanya dibagi dalam beberapa bagian, yaitu: (1) Sejarah Gereja Umum I; (2) Sejarah Gereja Umum II; (3) Sejarah Gereja Asia; dan (4) Sejarah Gereja Indonesia. Sejarah Gereja Umum I mempelajari perkembangan kekristenan sejak mulamula, ekspansi gereja, konsili-konsili oikumenis, periode Abad Pertengahan hingga memasuki zaman Rennaisans di 
Italia dan Eropa Utara. Sejarah Gereja Umum II mempelajari perkembangan kekristenan dari permulaan abad ke 16 masa Reformasi, Ortodoks Protestan, munculnya sekularisasi modern, denominasi-denominasi Protestan dan perkembangan misi gereja. Sejarah Gereja Asia mempelajari permulaan dan perkembangan kekristenan di Asia dengan memperhatikan kontribusi tokoh-tokoh Kristen dalam gereja-gereja di Asia. Sejarah Gereja Indonesia mempelajari permulaan dan perkembangan kekristenan di Indonesia dengan memperhatikan kontribusi tokohtokoh Kristen dalam gereja-gereja di Indonesia. Selain keempat bagian matakuliah tersebut, biasanya PTT/AK berdasarkan corak dan visi-misinya akan menambahkan mata kuliah sejarah gereja sesuai denominasi gereja sesuai corak PTT/AK tersebut.. Misalnya, Sejarah Gereja Pentakosta mempelajari permulaan dan perkembangan kekristenan yang beraliran Petakosta sejak mulai Pentakosta modern, kharismatik dan gelombang ketiga. Tujuan dari mata kuliah yang khas tersebut tentunya adalah untuk membentuk karakter pendidikan yang khas pula. ${ }^{25}$

\footnotetext{
${ }^{25}$ Kevin Tonny Rey, "RANCANG BANGUN FILSAFAT PENDIDIKAN KRISTEN YANG BERCIRIKAN INJILI-PENTAKOSTA: SEBUAH KAJIANAKSIOLOGIS PENTAKOSTALISME," Jurnal Antusias 2, no. 2 (September 1, 2012): 6283, accessed April 15, 2019, http://sttintheos.ac.id/ejournal/index.php/antusias/article/view/34.
}

Berdasarkan deskripsi mata kuliah dan kompetensi yang hendak dicapai, maka model pembelajaran berbasis portofolio dapat diterapkan dalam matakuliah Sejarah Gereja misalnya sebagai berikut: (1) Dosen menentukan tugas portofolio berdasarkan materi, contoh perkembangan denominasidenominasi gereja di Indonesia; (2) Dosen membagi kelas dalam kelompok-kelompok dan memberikan tema bahasan untuk setiap kelompok, contoh sejarah gereja GSJA, GBI, GKI dan lainnya serta dosen mengatur agar sekiranya dalam satu kelompok membahas gereja yang bukan tempat mereka melayani agar mereka memperoleh kekayaan pengetahuan yang baru; (3) Setiap kelompok perlu melakukan tinjauan pustaka baik melalui buku maupun situs internet yang terpercaya serta mendatangi salah satu gereja denominasi yang dimaksud secara berkala untuk melakukan pencarian data melalui dokumen atau wawancara dengan narasumber; Mengumpulkan data, menyaring dan menyunting informasasi, menyusun laporan secara sistematis, mempresentasikan secara timbal balik, mengkonsultasikan hasil pada dosen, dan akhirnya menyusun portofolio karya terpilih serta menggabungkan dengan karya terpilih seluruh kelompok kelas.

\section{Pembimbing Perjanjian Lama}

Mata kuliah Pembimbing Perjanjian 
Lama (PL) secara akademis dalam PTT/AK di Indonesia biasanya dibagi dalam beberapa bagian, yaitu: (1) Pembimbing PL I; dan (2) Pembimbing PL II. Pembimbing PL I mempelajari tetang latar belakang kitab-kitab dalam PL khususnya kitab Pentateukh sampai kitab-kitab Sejarah. Pembimbing PL II mempelajari tetang latar belakang kitab-kitab dalam PL khususnya kitab-kitab puisi sampai kitab Nabi-nabi kecil.

Berdasarkan deskripsi mata kuliah dan kompetensi yang hendak dicapai, maka model pembelajaran berbasis portofolio dapat diterapkan dalam matakuliah Pembimbing PL misalnya sebagai berikut: (1) Dosen menentukan tugas portofolio berdasarkan materi, contoh latar belakang dan garis besar kitab Nabi-nabi kecil; (2) Dosen membagi kelas dalam kelompokkelompok dan memberikan tema bahasan untuk setiap kelompok, contoh seluruh kitab Nabi-nabi kecil serta dosen mempetimbangkan jumlah pasal pada setiap kitab dan waktu yang dibutuhkan untuk setiap kelompok dapat menyelesaikannya; (3) Setiap kelompok perlu melakukan tinjauan pustaka baik melalui buku maupun situs internet yang terpercaya serta bertanya pada dosen, pendeta, atau pakar lainnya di luar kampus untuk menambah informasi;

Mengumpulkan data, menyaring dan menyunting informasasi, menyusun laporan secara sistematis, mempresentasikan secara timbal balik, mengkonsultasikan hasil pada dosen, dan akhirnya menyusun portofolio karya terpilih serta menggabungkan dengan karya terpilih seluruh kelompok kelas.

\section{Pembimbing Perjanjian Baru}

Mata kuliah Pembimbing Perjanjian Baru (PB) secara akademis dalam PTT/AK di Indonesia biasanya dibagi dalam beberapa bagian, yaitu: (1) Pembimbing PB I; dan (2) Pembimbing PB II. Pembimbing PB I mempelajari tetang latar belakang penulisan, sejarah, sosial, dan politik pada zaman PB khususnya Injil dan Kisah Para Rasul. Pembimbing PB II mempelajari tetang latar belakang penulisan, sejarah, sosial, dan politik pada zaman PB khususnya surat-surat Paulus sampai Wahyu.

Berdasarkan deskripsi mata kuliah dan kompetensi yang hendak dicapai, maka model pembelajaran berbasis portofolio dapat diterapkan dalam matakuliah Pembimbing PB misalnya sebagai berikut: (1) Dosen menentukan tugas portofolio berdasarkan materi, contoh latar belakang dan garis besar surat-surat Paulus; (2) Dosen membagi kelas dalam kelompokkelompok dan memberikan tema bahasan untuk setiap kelompok, contoh seluruh surat-surat Paulus serta dosen 
mempertimbangkan jumlah pasal pada setiap kitab dan waktu yang dibutuhkan untuk setiap kelompok dapat menyelesaikannya; (3) Setiap kelompok perlu melakukan tinjauan pustaka baik melalui buku maupun situs internet yang terpercaya serta bertanya pada dosen, pendeta, atau pakar lainnya di luar kampus untuk menambah informasi;

Mengumpulkan data, menyaring dan menyunting informasasi, menyusun laporan secara sistematis, mempresentasikan secara timbal balik, mengkonsultasikan hasil pada dosen, dan akhirnya menyusun portofolio karya terpilih serta menggabungkan dengan karya terpilih seluruh kelompok kelas.

\section{Homeletika}

Mata kuliah Homeletika secara akademis dalam PTT/AK di Indonesia mempelajari prinsip-prinsip ilmu berkhotbah, sehingga dapat membantu mahasiswa untuk menyusun khotbah dan dapat menyampaikan khotbah, serta memberikan dasar-dasar untuk menyusun khotbah yang baik dan Alkitabiah.

Berdasarkan deskripsi mata kuliah dan kompetensi yang hendak dicapai, maka model pembelajaran berbasis portofolio dapat diterapkan dalam matakuliah Homeletika misalnya sebagai berikut: (1) Dosen menentukan tugas portofolio berdasarkan materi, contoh khotbah tematik tentang buah Roh; (2) Dosen membagi kelas dalam kelompok-kelompok dan memberikan tema bahasan untuk setiap kelompok, contoh daftar buah Roh dan implementasinya dalam kehidupan; Setiap kelompok perlu melakukan tinjauan pustaka baik melalui Alkitab (eksegesa), buku teologi maupun situs internet yang terpercaya serta mendengarkan video khotbah atau menghadiri ibadah secara langsung seandainya terdapat tema khotbah yang berkaitan dengan buah Roh; (4) Mengumpulkan data, menyaring dan menyunting informasasi, menyusun laporan secara sistematis, salah satu anggota setiap kelompok mewakili untuk praktik berkhotbah, membuka ruang saran, mengkonsultasikan hasil pada dosen, dan akhirnya menyusun portofolio karya terpilih serta menggabungkan dengan karya terpilih seluruh kelompok kelas.

\section{Hermeneutika}

Mata kuliah Hermeneutika secara akademis dalam PTT/AK di Indonesia mempelajari prinsip-prinsip penafsiran Alkitab dan latihan-latihan menerapkan eksegesa yang tepat sehingga mendapatkan arti teks yang sebenarnya pada saat teks Alkitab ditulis dan menerapkan pada konteks masa kini.

Berdasarkan deskripsi mata kuliah dan kompetensi yang hendak dicapai, maka 
model pembelajaran berbasis portofolio dapat diterapkan dalam matakuliah Hermeneutika misalnya sebagai berikut: (1) Dosen menentukan tugas portofolio berdasarkan materi, contoh struktur teks puisi Amsal dan implementasinya dalam kehidupan; (2) Dosen membagi kelas dalam kelompok-kelompok dan memberikan tema bahasan untuk setiap kelompok, contoh seluruh pasal dalam Amsal dan implementasinya dalam kehidupan serta dosen mempetimbangkan jumlah pasal pada setiap kitab dan waktu yang dibutuhkan untuk setiap kelompok dapat menyelesaikannya; (3) Setiap kelompok perlu melakukan tinjauan pustaka baik melalui Alkitab (eksegesa), buku teologi maupun situs internet yang terpercaya serta bertanya pada dosen, pendeta, atau pakar lainnya di luar kampus untuk menambah informasi; (4) Mengumpulkan data, menyaring dan menyunting informasasi, menyusun laporan secara sistematis, mempresentasikan secara timbal balik, mengkonsultasikan hasil pada dosen, dan akhirnya menyusun portofolio karya terpilih serta menggabungkan dengan karya terpilih seluruh kelompok kelas.

\section{Dogmatika}

Mata kuliah Dogmatika secara akademis dalam PTT/AK di Indonesia biasanya dibagi dalam beberapa bagian, yaitu: (1) Kristologi dan Soteriologi; (2)

Eklesiologi dan Eskhatologi; serta (3)

Pneumatologi, Anggelologi dan Satanologi. Kristologi mempelajari tentang permasalahan-permasalahan Kristus dalam Alkitab dan kontemporer, Yesus sebagai tokoh sejarah dan Kristus Iman serta pandangan pandangan tengtang Kristus masa Kini. Soteriologi mempelajari tentang penerapan keselamatan oleh karena anugerah dan karya Kristus yang dimungkinkan menjadi pengalaman bagi orang-orang percaya oleh karena pekerjaan Roh Kudus. Eklesiologi mempelajari tentang hakekat, sifat-sifat, tugas dan tanggung jawab, sistem pemerintahan, pelayanan dan misi gereja yang ada di dunia menurut Alkitab. Eskhatologi mempelajari tentang peristiwa-peristiwa pada hari-hari yang akan datang, seperti pengangkatan Gereja, Kerajaan Seribu Tahun, penghakiman Terakhir, kedatangan Tuhan Yesus kedua kali, Bumi baru dan Neraka. Pneumatologi mempelajari tentang Roh Kudus sebagai oknum ketiga daripada Tritunggal Allah dalam PL dan PB, peranan dan pekerjaan Roh Kudus dalam pribadi orang percaya maupun tidak percaya. Anggelologi dan Satanologi mempelajari tentang asal-usul, karakter dan aktifitas Malaikat atau Setan di dalam maupun di luar gereja.

Berdasarkan deskripsi mata kuliah 
dan kompetensi yang hendak dicapai, maka model pembelajaran berbasis portofolio dapat diterapkan dalam matakuliah Dogmatika misalnya sebagai berikut: (1) Dosen menentukan tugas portofolio berdasarkan materi, contoh pandangan Kekristenan tentang akhir zaman; (2) Dosen membagi kelas dalam kelompok-kelompok dan memberikan tema bahasan untuk setiap kelompok, contoh Premillenium, Amillenium, dan Postmillenium; (3) Setiap kelompok perlu melakukan tinjauan pustaka baik melalui buku dogmatika maupun situs internet yang terpercaya bertanya pada dosen, pendeta, atau pakar lainnya di luar kampus untuk menambah informasi; (4) Mengumpulkan data, menyaring dan menyunting informasasi, menyusun laporan secara sistematis, mempresentasikan secara timbal balik, mengkonsultasikan hasil pada dosen, dan akhirnya menyusun portofolio karya terpilih serta menggabungkan dengan karya terpilih seluruh kelompok kelas.

\section{Hasil Temuan untuk Meningkatkan}

\section{Tanggung Jawab Belajar Mahasiswa} STT

Model pembelajaran berbasis portofolio dapat meningkatkan tanggung jawab belajar mahasiswa di STT apabila model tersebut diterapkan dengan pertimbangan dan prosedural sebagai berikut:

(1) Tujuan dari membagi kelas dalam kelompok-kelompok yang lebih kecil adalah supaya terjadi interaksi yang lebih efektif karena setiap mahasiswa akan memperoleh kesempatan dan tanggung jawab yang sama dalam mengerjakan tugas. Dosen perlu menempatkan anggota setiap kelompok secara unik, variatif, dan merata serta menentukan seseorang yang berkapasitas menjadi pemimpin kelompok, pemimpin inilah yang akan mengkoordinasi dan membagi tugas terhadap anggotanya. Dalam tahap ini dosen juga berkesempatan melakukan penilaian proses belajar terhadap mahasiswa secara individu mapun kelompok.

(2) Tugas yang dosen berikan sebisa mungkin diatur agar mahasiswa dalam proses pengerjaan tugas tersebut perlu melakukan tahap interaksi dengan lingkungan di dalam maupun di luar kampus. Hal ini ditujukan agar mahasiswa memperoleh perluasan materi dan meningkatkan kompetensi sosialnya. Dalam tahap ini juga mahasiswa akan terlatih dalam berkomunikasi, bersosialisasi serta mempertanggungjawabkan data yang mereka peroleh baik secara lisan maupun tulisan dari narasumber.

(3) Dosen perlu memberi pemahaman bahwa makna pemberian tugas berupa portofolio adalah "karya terbaik." Dengan 
menggunakan istilah tersebut diharapkan mahasiswa akan termotivasi untuk maksimal dalam mengerjakan tugasnya. Tahap ini juga perlu didukung dengan dosen memberikan penguatan pembelajaran reward agar mahasiswa merasa bahwa hasil pemikirannya mendapatkan apresiasi dan tidak sia-sia meskipun belum sempurna.

(4) Hasil pengerjaan tugas perlu dipresentasikan secara umpan balik agar hasilnya lebih berbobot, lebih teruji, dan lebih dapat dipertanggung jawabkan baik oleh mahasiswa maupun dosen sebagai fasilitator. Tahap ini juga dapat didorong dengan mengatakan bahwa hasil tugas akan dijilid sedemikian rupa dan dipublikasikan. Dengan demikian mahasiswa akan lebih terpacu untuk menyusun tugas secara lebih sistematis karena mengetahui bahwa karyanya akan dibaca oleh orang lain dan bermanfaat.

(5) Salah satu prinsip pelaksanaan model pembelajaran berbasis portofolio adalah pembelajaran yang menyenangkan (joyfull Learning). Maka dosen juga perlu mempertimbangkan bobot tugas yang diberikan agar tidak berbalik menimbulkan kejenuhan. Apabila mahasiswa mengerjakan suatu tugas dengan senang hati maka mereka juga akan mengerjakanya dengan lebih bertanggung jawab karena mereka menikmati apa yang mereka kerjakan tanpa tekanan.

\section{KESIMPULAN}

Model pembelajaran berbasis portofolio diterapkan dengan mempertimbangkan kecocokan materi kuliah dan tujuan perkuliahan yang hendak dicapai. Tidak semua sub materi dalam matakuliah PTT/AK (yang telah disebutkan dalam penelitian ini) cocok menggunakan model pembelajaran berbasis portofolio (sebaliknya matakuliah yang belum disebutkan dalam penelitian ini memiliki kemungkinan efektif menggunakan model pembelajaran berbasis portofolio). Model pembelajaran ini dapat meningkatkan tanggung jawab belajar mahasiswa di STT apabila: (1) Setiap mahasiswa dipastikan mendapat bagian dalam tugas kelompok; (2) Tugas di-setting sedemikian rupa agar dalam proses pengerjaannya memerlukan proses interaksi sosial; (3) Mahasiswa dimotivasi melalui pemaknaan istilah "karya terbaik" serta diberi penguatan pembelajaran reward; (4) Hasil portofolio diusakan untuk dipublikasikan untuk meningkatkan standar dalam proses pengerjaannya; dan (5) Dosen perlu terlebih dahulu memahami dan membiasakan menggunakan model ini agar lebih efektif dan maksimal.

\section{DAFTAR PUSTAKA}

Andrianti, Sarah. "PENDEKATAN PEMBELAJARAN BERPUSAT PADA SISWA DALAM 
PENDIDIKAN AGAMA KRISTEN SEBAGAI IMPLEMENTASI KURIKULUM 2013." Jurnal Antusias 3, no. 5 (June 1, 2014): 86-102. Accessed April 15, 2019. http://sttintheos.ac.id/ejournal/index.php/antusias/article/view $/ 14$.

Birgin, Osman, and Baki Adnan. "The Use of Portfolio to Assess Student's Performance." Journal of Turkish Science Education 4, no. 2 (2007). http://www.tused.org/internet/tused/sa yilar/defaultarchive.asp?islem=detayla r\&id=111.

Djamarah, Syaiful Bahri. Strategi Belajar Mengajar. Jakarta: Rineka Cipta, 2013.

Fajar, Arnie. Portofolio Dalam Pelajaran IPS. Bandung: PT Remaja Rosdakarya, 2002.

Hadi, Sutrisno. Statistik II. Jakarta: Rineka Cipta, 1995.

Hastuti, Ruwi. "KESIAPAN SEKOLAH TINGGI TEOLOGI MENGHADAPI KURIKULUM 2013." Jurnal Antusias 3, no. 5 (June 1, 2014): 103-116. Accessed April 15, 2019. http://sttintheos.ac.id/ejournal/index.php/antusias/article/view $/ 15$.

Karimah, Isyatul, Wahyu Sakti Gunawan Irianto, and I Made Wirawan. "PENERAPAN PENILAIAN PORTOFOLIO PEMBELAJARAN GURU SMKN DI KELAS X PADA MATA PELAJARAN PEMROGRAMAN WEB." Jurnal Pendidikan: Teori, Penelitian, dan Pengembangan 2, no. 11 (November 1, 2017): 1482-1488. Accessed April 14,2019 http://journal.um.ac.id/index.php/jptpp /article/view/10178.

Madyarini, Dyan Desi, and Abdul Gafur. "KOMPARASI MODEL
PEMBELAJARAN PORTOFOLIO DAN PBL TERHADAP HASIL BELAJAR IPS DI SMPN KECAMATAN SEWON." Harmoni Sosial: Jurnal Pendidikan IPS 2, no. 2 (September 30, 2015): 126-134. Accessed April 14, 2019. https://journal.uny.ac.id/index.php/hsj pi/article/view/7664.

Marno. "Optimalisasi Media Pembelajaran Melalui Teknik Problem Based Instruction Untuk Meningkatkan Hasil Belajar Kelas XI SMA Negeri 1 Surakarta Tahun 2016/2017." Jurnal Pendidikan Konvergensi 20, no. 67 (2017).

Mokhtaria, Lahmer. "The Use Of Portfolio As An Assessment Tool" 4, no. 07 (2015): 170-172.

Murdiono, Mukhamad. Strategi Pembelajaran Kewarganegaraan Berbasis Fortofolio, 2012.

Noeng, Muhadjir. Metodologi Penelitian Kualitatif. Yogyakarta: Rake Sarasin, 1998.

Rey, Kevin Tonny. "RANCANG BANGUN FILSAFAT PENDIDIKAN KRISTEN YANG BERCIRIKAN INJILI-PENTAKOSTA: SEBUAH KAJIANAKSIOLOGIS PENTAKOSTALISME." Jurnal Antusias 2, no. 2 (September 1, 2012): 62-83. Accessed April 15, 2019. http://sttintheos.ac.id/ejournal/index.php/antusias/article/view 134 .

Rohani, Rohani, and Tri Indah Kesumawati. "Pengaruh Pembelajaran Berbasis Portofolio Dan Kemampuan Awal Terhadap Hasil Belajar Mahasiswa Prodi PIAUD." $A L$ ATHFAL : JURNAL PENDIDIKAN $A N A K$ 4, no. 2 (December 31, 2018): 187-198. Accessed April 14, 2019. http://ejournal.uinsuka.ac.id/tarbiyah/index.php/alathfal/ article/view/42-06. 
Setiadi, Elly M. Ilmu Sosial Dan Budaya Dasar. Jakarta: Kencana, 2006.

Sugiyono. Metode Penelitian Kuantitatif, Kualitatif Dan Research \& Defelopment. Bandung: Alfabeta, 2013.

Supriadi, Acep. Kemampuan Guru Memanfaatkan Asesmen Portofolio Dalam Meningkatkan Mutu Belajar Pendidikan IPS Di Sekolah Dasar. Bandung: UPI, 1997.

Taniredja, Tukiran. Model-Model Pembelajaran Inovatif Dan Efektif. Bandung: Alfabeta, 2017.

Trianto. Mendesain Model Pembelajaran Inovatif-Progresif. Jakarta: Kencana Prenada Media Group, 2010.
Warsita, Bambang. Teknologi Pembelajaran: Landasan \& Aplikasinya. Jakarta: Rineka Cipta, 2008.

Zed, Mestika. Metode Penelitian Kepustakaan. Jakarta: Yayasan Obor Indonesia, 2004.

Zuchdi, Darmiyati. Pendidikan Karakter: Konsep Dasar Dan Implementasi Di Perguruan Tinggi. Yogyakarta: UNY Press, 2013.

Panduan Kurikulum Stratum Satu (S1) Prodi Pendidikan Agama Kristen Sekolah Tinggi Teologi Dan Sekolah Tinggi Agama Kristen Di Indonesia. Jakarta: Direktorat Jenderal Bimbingan Mayarakat Kristen, 2011. 